\title{
Clean Coal Technologies - An International Seminar: Seminar Evaluation and Identification of Potential CCT Markets
}

Environmental Assessment and Information Sciences Division Argonne National Laboratory

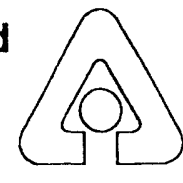

Operated by The University of Chicago, under Contract W-31-109-Eng-38, for the United States Department of Energy 


\section{Argonne National Laboratory}

Argonne National Laboratory, with facilities in the states of Illinois and Idaho, is owned by the United States government, and operated by the University of Chicago under the provisions of a contract with the Department of Energy.

This technical report is a product of Argonne's Environmental Assessment and Information Sciences Division. For information on the division's scientific and engineering activities, contact:

Director, Environmental Assessment and Information Sciences Division

Argonne National Laboratory

Argonne, Illinois 60439-4815

Telephone (708) 972-3759

\section{Disclaimer}

This report was prepared as an account of work sponsored by an agency of the United States Government. Neither the United States Government nor any agency thereof, nor any of their employees, makes any warranty, express or implied, or assumes any legal liability or responsibility for the accuracy, completeness, or usefulness of any information, apparatus, product, or process disclosed, or represents that its use would not infringe privately owned rights. Reference herein to any specific commercial product, process, or senvice by trade name, trademark, manufacturer, or otherwise, does not necessarily constitute or imply its endorsement, recommendation, or favoring by the United States Government or any agency thereof. The views and opinions of authors expressed herein do not necessarily state or reflect those of the United States Government or any agency thereof.

Reproduced from the best available copy. Available from the National Technical Information Service (NTIS), U.S. Department of Commerce, 5285 Port Royal Road, Springfield, Virginia 22161.

NTIS price codes:

Printed copy $\mathrm{AO} 3$

Microfiche 


\section{Clean Coal Technologies - An International Seminar: Seminar Evaluation and Identification of Potential CCT Markets}

by K.A. Guziel, L.A. Poch, J.L. Gillette, and W.A. Buehring

Environmental Assessment and Information Sciences Division, Argonne National Laboratory, 9700 South Cass Avenue, Argonne, Illinois 60439

July 1991

Work sponsored by United States Department of Energy, Assistant Secretary for Fossil Energy; United States Agency for International Development; and United States Trade and Development Program 


\section{CONTENTS}

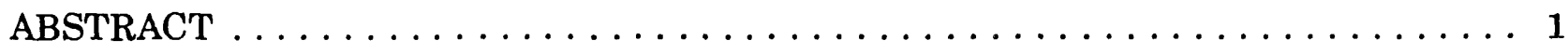

1 INTRODUCTION $\ldots \ldots \ldots \ldots \ldots \ldots \ldots \ldots \ldots \ldots \ldots \ldots \ldots \ldots \ldots \ldots \ldots \ldots \ldots$

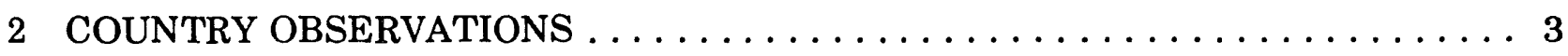

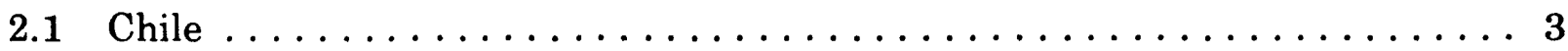

2.2 Costa Rica ............................... 4

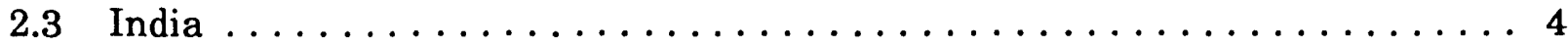

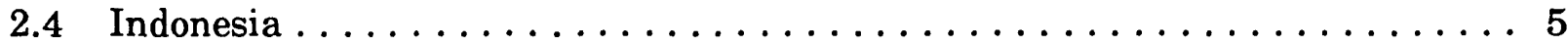

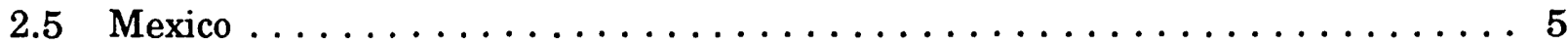

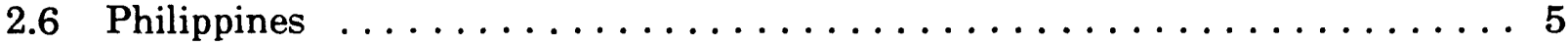

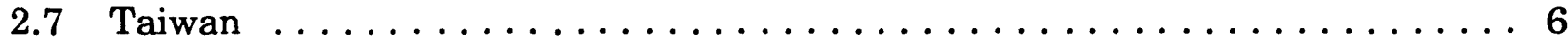

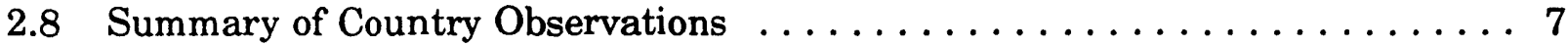

3 PARTICIPANT COMMENTS AND SUGGESTIONS $\ldots \ldots \ldots \ldots \ldots \ldots \ldots$

4 ARGONNE OBSERVATIONS AND RECOMMENDATIONS $\ldots \ldots \ldots \ldots \ldots \ldots$

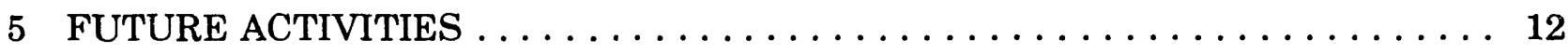

APPENDIX A: List of Participants $\ldots \ldots \ldots \ldots \ldots \ldots \ldots \ldots \ldots \ldots \ldots \ldots \ldots \ldots$

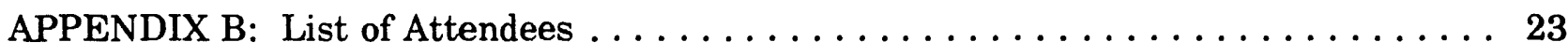

APPENDIX C: Seminar Schedule $\ldots \ldots \ldots \ldots \ldots \ldots \ldots \ldots \ldots \ldots \ldots \ldots$

APPENDIX D: Quantitative Evaluation Results $\ldots \ldots \ldots \ldots \ldots \ldots \ldots \ldots \ldots$

TABLE

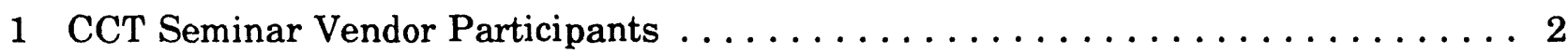




\title{
CLEAN COAL TECHNOLOGIES -- AN INTERNATIONAL SEMINAR: SEMINAR EVALUATION AND IDENTIFICATION OF POTENTIAL CCT MARKETS
}

by

\author{
K.A. Guziel, L.A. Poch, J.L. Gillette, and W.A. Buehring
}

\begin{abstract}
The need for environmentally responsible electricity generation is a worldwide concern. Because coal is available throughout the world at a reasonable cost, current research is focusing on technologies that use coal with minimal environmental effects. The United States government is supporting research on clean coal technologies (CCTs) to be used for new capacity additions and for retrofits to existing capacity. To promote the worldwide adoption of U.S. CCTs, the U.S. Department of Energy, the U.S. Agency for International Development, and the U.S. Trade and Development Program sponsored a two-week seminar titled Clean Coal Technologies -- An International Seminar. Nineteen participants from seven countries were invited to this seminar, which was held at Argonne National Laboratory in June 1991. During the seminar, 11 U.S. CCT vendors made presentations on their state-ofthe-art and commercially available technologies. The presentations included technical, environmental, operational, and economic characteristics of CCTs. Information on financing and evaluating CCTs also was presented, and participants visited two CCT operating sites. The closing evaluation indicated that the seminar was a worthwhile experience for all participants and that it should be repeated. The participants said CCT could play a role in their existing and future electric capacity, but they agreed that more CCT demonstration projects were needed to confirm the reliability and performance of the technologies.
\end{abstract}

\section{INTRODUCTION}

The seminar titled Clean Coal Technologies -- An International Seminar was cosponsored by the U.S. Department of Energy (DOE), the U.S. Agency for International Development (AID), and the U.S. Trade and Development Program (TDP). The seminar was attended by 19 participants from the countries of Chile, Costa Rica, India, Indonesia, Mexico, the Philippines, and Taiwan. The seminar was hosted by Argonne National Laboratory and conducted at its facilities near Chicago, Illinois.

The purpose of the seminar was to provide a forum for U.S. clean coal technology (CCT) vendors to present their state-of-the-art and commercially available technologies. The seminar included vendor presentations on the technical, environmental, operational, and economic characteristics of the technologies and methods for analyzing their competitiveness. Seminar participants were middle- and senior-level managers who have the power to affect the decision to select CCTs for new capacity additions and other applications. The participants were selected by the seminar sponsors. (See Appendix A for a list of seminar participants.) 
The seminar program included presentations by $10 \mathrm{CCT}$ vendor companies; two scheduled site visits; and information on evaluating economic competitiveness, financing, and private power considerations. Appendix B lists seminar attendees, and Appendix $C$ shows the seminar program schedule. Table 1 lists the vendors who made presentations during the seminar.

In addition to the vendor and technical presentations, members of each country team prepared and delivered two presentations. The first preseitation described their country's energy system situation (e.g., existing system capacity, indigenous resources, load growth, etc.). The second presentation focused on the role CCTs could play in their existing and future power systems.

During the seminar, participants visited two operating CCT sites: the Destec Energy plant in Plaquemine, Louisiana, and the Tidd plant in Brilliant, Ohio. The Destec Energy facility is a 161-MW integrated gasification combined cycle (IGCC) unit. The Destec plant is owned and operated by Louisiana Gasification Technology, Inc. (LGTI). The Tidd plant is a 70-MW pressurized fluidized bed combustion (PFBC) unit. The Tidd plant is jointly funded by the American Electric Power Company, the State of Ohio's Coal Development Office, and DOE.

In addition to the two scheduled CCT site visits, some of the participants visited the MC Power facilities in Burr Ridge, Illinois. MC Power is conducting research on molten carbonate fuel cells. Fuel cell components are designed, manufactured, and tested at the Burr Ridge facility.

TABLE 1 CCT Seminar Vendor Participants

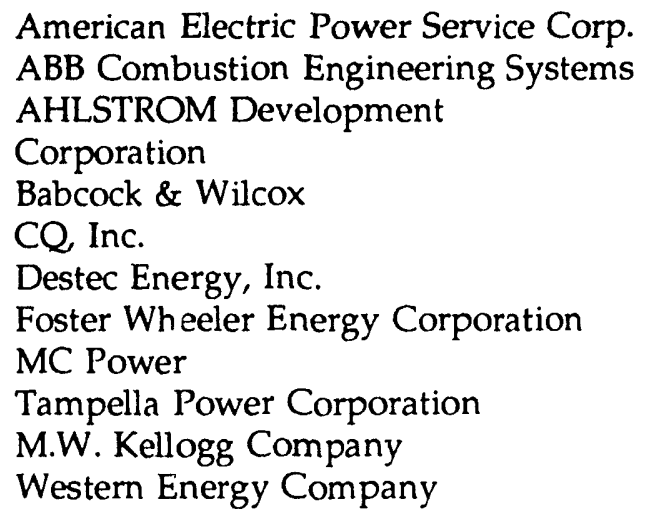




\section{COUNTRY OBSERVATIONS}

This section summarizes the two presentations made by each country team during the seminar. The first presentation described the country's national energy situation and CCTs' potential. The second presentation summarized the preliminary analyses conducted by the country team and identified candidate CCTs for the country. The points expressed in this chapter are summarized from the statements made by the country representatives. These statements were expressed as the representatives' personal opinions and should not be interpreted as the official policy of their country or organization nor as positions taken by Argonne National Laboratory, DOE, AID, or TDP.

\subsection{CHILE}

Chile has large coal deposits. In a report by the National Energy Commission (1989), proven reserves total 194 million metric tons, probable reserves are estimated at 441 million metric tons, and possible reserves are estimated at 5,120 million metric tons.

As in many countries around the world, emission regulations could be a factor in the choice of fuels and technologies for future electric power plants in Chile. National regulations on emission standards are expected in 1992, and it is expected that the regulations will approach U.S. standards for particulates and $\mathrm{SO}_{2}$. However, it is thought that $\mathrm{NO}_{\mathrm{x}}$ emissions will not be regulated for at least another 5 to 10 years. In order to meet emission standards in the short term, Chilgener (one of the electric utilities in Chile) plans to use precipitators and flue gas desulfurization units.

Current electric system expansion plans call for three 125-MW coal-fired plants to be in operation by 1997 at the Guacolda and Tocopilla sites and a total of 600 to $900 \mathrm{MW}$ of capacity to be in operation by 2002 at the Ventanas site. The Chilean representatives (management staff of Chilgener S.A.) said the Ventanas plant was a potential candidate for C C $\mathrm{i}$ retrofit (possibly fluidized bed combustors). New units at Ventanas are not scheduled until after 2000. Because the environmental regulations will be in place by then, CCTs are a viable alternative for these units.

Of particular interest to the Chileans was the SYNCOAL technology discussed by the representative of Western Energy Company. This process could be used to upgrade large deposits of subbituminous coal of low heating value $(4,000 \mathrm{kcal} / \mathrm{kg}$ or $7,215 \mathrm{Btu} / \mathrm{lb})$ located in the south of Chile (Magellanes area). Currently this coal is used only in a mine-mouth thermal power plant owned by Codelco, the national copper-mining company. Studies on this coal indicate its potential use in future coal-fired power plants, but its low heating value makes the shipping costs very high. Furthermore, blending this coal with bituminous coal would require more pulverizer capacity and a larger boiler, which would add about U.S. $\$ 100 / \mathrm{kW}$ to the capital cost of a plant. However, upgrading this coal via the SYNCOAL process could make the coal an attractive option for use in future pulverized-coal power stations designed to use bituminous coal only. The Chilean team estimated that if, instead of using this coal directly as mined, it were cleaned by the SYNCOAL process and then transported to the Ventanas site to be used in an existing 325-MW plant, the result would be savings of U.S. $\$ 6.7$ million. 


\subsection{COSTA RICA}

Costa Rica has vast hydropower resources. Thermal power plants are used mainly in remote areas that are not part of the interconnected system or to provide power to the interconnected system in times of inadequate hydropower. Overall, thermal power plants make up just over $22 \%$ of the total installed generating capacity of Costa Rica and only about $9 \%$ of the installed capacity of the interconnected system. However, recent droughts and increasing power demands have indicated a need for additional thermal power plants. Unpredictable weather, along with the desire to use the indigenous subbituminous coal resources in Costa Rica, makes CCT a potential option for future coal-fired power plants.

The Costa Rican national utility, Instituto Costarricense de Electricidad (ICE), and Spain (ENDESA) are performing a feasibility study for a 75-MV coal-fired power plant expected to come on line in 1997. The participants from Costa Rica (staff members of ICE) said that this seminar was their first exposure to CCT and that although the current feasibility study does not include CCT as an alternative, they may want to consider this option in the future.

\subsection{INDIA}

In order to satisfy new demand for power as well as suppressed demand (i.e., existing demand that cannot be satisfied because of insufficient or unreliable generation), India has a very ambitious generation expansion plan. In the next five years, more than $24,000 \mathrm{MW}$ of new capacity is planned to come on line, followed by an additional 70,000 MW of new capacity from $1994 / 95$ to $1999 / 2000$.

India has indigenous coal and currently uses coal for power generation. Total estimated coal reserves are about 176 billion metric tons, and current annual coal production is 201 million metric tons. About $60 \%$ of current coal production is used for power generation. The characteristics of Indian coal are: high ash content (35-40\%), low calorific value, and low sulfur content. Furthermore, there are vast distances between coal-mining regions and demand centers.

India is very interested in using CCTs. The government's ambitious generation expansion plan, along with increasing environmental regulations and the desire to increase reliance on indigenous energy resources, makes CCT a viable solution. A feasibility study has been conducted jointly with AID funding by an Indian team and Bechtel to evaluate the use of coal for an IGCC unit. As a first step toward commercialization, a demonstration plant is expected to be constructed by 1995 . The market penetration rate is estimated to be $5-10 \%$ in the first 10 years following demonstration, and the initial potential capacity estimate is 5,000 MW. In addition to the ability to burn coal cleanly, IGCC units produce elemental sulfur, for which there is a high demand in India. Other CCTs under consideration are coal beneficiation and fluidized bed combustion.

The representatives from India (who were from the Ministry of Energy and the Council of Scientific and Industrial Research) said they thought cogeneration had only a limited potential. There is no domestic heating load; only process industries have some useful application for cogeneration. At present, cogeneration exists in certain fertilizer plants and in the sugar and paper industries. 


\subsection{INDONESIA}

Because oil is the main source of the Indonesian government's export earnings, electric power developers are encouraged to use nonoil energy resources such as hydropower, coal, and geothermal power. Indonesia has substantial coal reserves (about 23 trillion tons), but the coal characteristics can vary greatly. Under the current five-year plan (1994/95 to 1998/99), Indonesia will develop $8,315 \mathrm{MW}$ of coal-fired power plants. This figure includes 7,800 $\mathrm{MW}$ in Java (2,600 MW by PLN, the state electricity company, and 5,200 MW by the private sector) and 515 MW outside Java (all by PLN). The participants from Indonesia (two from PLN and one from the Directorate General of Electric Power and New Energy) said they thought that because of the increasing environmental regulations in their country, using CCTs for future coal-fired power plants may be appropriate. Plans call for low- $\mathrm{NO}_{\mathrm{x}}$ burners to be installed in several future coal-fired units listed in the current five-year plan.

The Indonesian team said that in the longer term several different CCTs could be used in planned coal-fired plants. For example, cyclone burners and slagging combustors were identified as possibilities for ten 600-MW plants scheduled to be on line between 1999 and 2003, five 25-MW plants scheduled to be on line between 1996 and 1999, and four 45-MW plants scheduled to be on line between 1995 and 2001. It is also possible to use atmospheric or pressurized fluidized bed combustion (AFBC/PFBC) technology in the four 45-MW and five $25-\mathrm{MW}$ plants. Use of IGCC technology is possible in the five $25-\mathrm{MW}$ plants, as well as in two $50-\mathrm{MW}$ plants scheduled to be on line between 2003 and 2004 and two 65-MW plants scheduled to be on line between 1995 and 1997.

Before CCTs are considered as possible expansion candidates, Indonesia's techrology maturity requirement must be met; that is, a technology must have been commercially demonstrated in two units, each with at least three years of operation, in the size range Indonesia is considering. The Indonesian representatives said they thought that IGCC technology might have potential for use in the 500-MW size needed in Java, but that there were no units of that size currently in operation.

\subsection{MEXICO}

In order to satisfy a $7 \%$ yearly growth rate in electric demand through the year 2000 , Mexico is planning $12,200 \mathrm{MW}$ of new capacity. This expansion plan will include 3,300 MW of capacity using domestic coal and $8,900 \mathrm{MW}$ from dual-fired power plants, which will use either imported coal or oil. Indigenous coal reserves have been estimated at about 1,250 million tons. CCTs are an attractive option because the Mexican government is developing new and stricter air pollution regulations. Furthermore, the Mexican participant (who was from the Directorate General of Research and Development) said the government was interested both in retrofitting environmental control systems to existing power plants and in using IGCC technology for new plants.

\subsection{PHILIPPINES}

The Philippines remain highly dependent upon imported oil for energy. Oil accounts for $62 \%$ of primary energy consumption, with $80 \%$ imported from the Middle East. In order to 
reduce this dependency, the government has adopted a policy of energy self-reliance, focusing on development of indigenous resources and judicious energy use.

In order to develop its coal industry, the government adopted a strong coal-conversion program during the 1980s. Cement-manufacturing plants were encouraged to switch from oil to coal, and the National Power Corporation (NPC) began building coal-fired power plants as part of its power development program. Coal terminals were built for domestic movement of coal resources and for handling imported coal. During this period, the private sector also built coal-fired power plants.

The country's potential coal reserves are estimated at about 1.6 billion metric tons, of which 252 million metric tons are considered recoverable. These reserves are capable of supporting 1,820 MW of coal-fired power plants. About $57 \%$ of the reserves are lignite deposits located in two areas: one on the island of Semirara and the other in the northern part of Luzon. The remaining coal reserves are scattered throughout the archipelago. The deposits are fairly young, are of relatively low quality, and have a high sulfur content.

Currently, electric power generation from coal totals $535 \mathrm{MW}$, or $8 \%$ of the country's total capacity. These figures include privately owned plants. However, NPC estimates future electric capacity additions at 10,699 MW. Of this amount, 5,920 MW (56\%) are expected to be coal fired.

The representatives of the Philippines (who were from the Office of Energy Affairs and NPC) said they thought that beneficiation of low-rank coals might be a possible application of CCT. Coal beneficiation currently is not performed on domestic coal. Fi:rthermore, because the Philippines do not have enough indigenous coal reserves 't's support all the projected future coalfired capacity, there appears to be a need for additional coal imports.

\subsection{TAIWAN}

Taiwan projects a high growth rate for the period of $1990-2006$ (5.6\% for the average load and $6.0 \%$ for the peak load). The installed electric generation capacity of the Tai wan Power Company (Taipower) is expected to double from its current level of 17,000 MW to more than $36,000 \mathrm{MW}$. Of that additional capacity, 13 units totaling 8,150 MW are expected to be coal fired. Current coal-fired capacity consists of 10 units generating a total of 3,675 MW. Indigenous coal supplies only $3 \%$ of the total demand; the remaining $97 \%$ is imported from Australia, the United States, Canada, South Africa, and Indonesia.

Coal consumption is projected to rise from 19 million tons in 1990 to 35 million tons in 2000. As a result, the government of Taiwan has imposed regulations limiting pollutant emissions from coal combustion. Taiwan is seriously considering CCTs in order to accommodate the expanded use of coal in an environmentally acceptable manner. The Taiwan representatives (who were from the Taiwan Power Company, the Ministry of Economic Affairs, and the Energy and Resource Laboratory) assessed the potential of several CCTs during the course of the seminar. They are (in order of priority): IGCC, circulating fluidized bed comoustion (CFBC), dry and wet flue gas desulfurization (FGD), low- $\mathrm{NO}_{\mathrm{x}}$ burning, and coal blending.

- IGCC -- Although studies have shown that IGCC units are more efficient and offer better environmental protection than conventional power plants, 
Taipower is reluctant to build a large unit (500 MW or larger) because the reliability of large commercialized units has not been demonstrated. Most IGCC units are still in the demonstration stage; the largest IGCC unit in the world is only $161 \mathrm{MW}$. Taipower prefers to wait until the technology is more mature, particularly for the larger sizes.

- CFBC -- The potential uses of CFBC in Taiwan are in cogeneration and waste incineration. Because of electricity shortages, the Taiwan government encourages large industrial companies to use cogeneration. Because Taiwan produces 36 million tons of waste annually, some waste must be incinerated. Taiwan currentiy operates incinerators in the fixed-bed mode, but CFBC units are expected to operate more efficiently.

- FGD -- This technology probably will play the most important role of all CCTs. Currently, five wet FGD units and one dry FGD unit are in operation. Taipower plans call for installation of 11 additional FGD units a $c$ its existing plants. Wet FGD units most likely will be used in utility applications, while dry FGD units will be used in small industrial applications.

- Low- $\mathrm{NO}_{\mathrm{x}}$ Burning -- Taipower is expected to install low- $\mathrm{NO}_{\mathrm{x}}$ burners on all of its power plants.

- Coal Blending -- Taiwan buys large amounts of coal from various sources. Because of political and economic concerns, the purchase of low-quality coal cannot be avoided. Feasibility studies have shown that coal blending can improve the quality of low-grade coal that Taiwan currently uses.

\subsection{SUMMARY OF COUNTRY OBSERVATIONS}

The seven countries participating in the CCT seminar represent a wide spectrum of current and projected coal use. Nonetheless, there was a general consensus that CCTs can play an important role in meeting increasingly stringent air emission requirements while expanding industrial and electrical sectors. Countries currently using coal-combustion technologies for generating electricity anticipate that the post-combustion CCTs (e.g., flue gas desulfurization) and combustion-modification technologies such as low- $\mathrm{NO}_{x}$ burners could be applied in their countries. Some of the countries with indigenous coal supplies expressed interest in the coal beneficiation and upgrading technologies in order to produce a more marketable fuel or to reduce their fuel transport and preparation costs.

Most of the participating countries expressed a strong interest in the combustion or conversion CCTs for expanding their electricity generation systems. The IGCC, AFBC, and PFBC technologies were considered favorably as longer-term options. Participants strongly expressed that these technologies are not yet commercial and that ongoing demonstrations must continue before they will consider using these technologies. The Indonesian participants stated this opinion formally by saying that a technology must be demonstrated in at least two units with a minimum operation of three years each before they can consider it as an alternative. 
It is the belief of the Argonne staff who conducted this seminar that the participants may have overlooked several opportunities for CCT applications. Several of these countries rely heavily on oil-fired capacity for electrical generation and/or the ind ustrial sector. These plants often could be retrofit with slagging combustors or with combustors for coal-water slurries, thereby shifting these units from oil-fired generation to coal-fired. Other opportunities that may have been overlooked involve the repowering of oil- or gas-fired combustion turbines into IGCC units. Although IGCC technology was noted by almost all participants as a long-term candidate for CCT applications, the perceived application was for sizes of $300 \mathrm{MW}$ or greater, and there is not yet a demonstration project for this size. However, by combining existing combustion turbines with heat-recovery steam generators and gasifiers, IGCC units very similar in size to those at Destec and Coolwater can be created. Thus, experience does exist that is applicable to the situations in these countries, and near-term applications for this CCT may have been overlooked. 


\section{PARTICIPANT COMMENTS AND SUGGESTIONS}

At the end of the seminar, the participants were asked to complete a written evaluation rating each presentation and activity on a scale of 1 to 4 , with 1 corresponding to "most valuable," 2 corresponding to "valuable," 3 corresponding to "somewhat valuable," and 4 corresponding to "not valuable." (This rating implies that the lower the average score the more valuable the activity was considered to be.) In addition to the ratings of the individual presentations, several other questions were asked regarding the structure of the seminar and its overall focus. The average evaluation scores and other results are found in Appendix D. The following paragraphs summarize the general findings from the written and verbal evaluations.

The seminar length was considered to be just right by most of the participants. The major components of th eminar were vendor presentations, site visits, financial presentations, country presentations, and technical presentations. Most participants said the amount of time allocated to vendor and country presentations was just right. However, some participants indicated that fewer and/or shorter vendor presentations would be desirable.

The reaction to the financial presentations was divided: $44 \%$ of the participants indicated that the amount of time devoted to financial presentations was just right, but a nother $44 \%$ indicated that the amount of time was too much. This finding is confirmed by the individual ratings of the financial presentations. These ratings are clustered in the valuable to somewhat valuable categories.

Sixty-eight percent of the participants said the time devoted to site visits was too short. The time spent at the Destec facility was limited because of a delay in leaving the hotel and because the flight connections from New Orleans to Pittsburgh (for the Tidd plant site visit) were limited. Fifty-eight percent of the participants indicated that the time devoted to technical presentations was too short. The scope and number of technical presentations was constrained by the seminar schedule and focus.

As part of the seminar, tro spreadsheet tools were presented to provide a method of analyzing the economic competitiveness of CCTs. Of the participants who responded, approximately $70 \%$ used one or both of the spreadsheets. The participants were very eager to examine the spreadsheet tools presented; however, not all vendors presented data that could be analyzed with the spreadsheets. In addition, several participants commented that they needed more time to work with the spreadsheets. Factors such as a busy schedule and inaccessibility of the computers in the evening limited the amount of time the participants could work with the spreadsheets.

Several of the participants emphasized in their written and verbal comments that most of the CCTs presented are not currently available on a commercial basis. In order to evaluate these technologies in conjunction with existing technologies, they said they needed firm cost data and operational experience from the demonstrations now under way.

All participants indicated that the amount of printed material distributed was adequate. 


\section{ARGONNE OBSERVATIONS AND RECOMMENDATIONS}

The objective of this seminar was to provide an overview of U.S. CCTs to representatives from foreign countries in which CCTs could be adopted. The overview of the CCTs included information on their technical, environmental, operating, and economic characteristics, as well as methods for analyzing their economic competitiveness. The objective was met by providing U.S. CCT vendors the opportunity to meet with representatives of countries where CCTs could be a viable option.

The overview of CCTs presented was good, but it did not cover all CCTs that might have been applicable to the participating countries. It should be noted that the level of familiarity with CCTs among the seminar participants ranged from novice to very knowledgeable. Participant selection criteria could be developed for future seminars. We suggest that selection of future seminar participants be targeted to senior-level managers who are familiar with coal technologies. We also recommend that replacement candidates be subject to the same criteria.

The goal to provide technical, environmental, operational, and economic characteristics of the CCTs was not entirely met. All the vendors did not provide explicit cost and operating data for their technologies. Although this information was requested of the vendors in the invitation letter, it was impossible to ensure that the information was provided. The lack of operating and cost data resulted in the participants' perception that most presented technologies were not commercially available. We suggest that vendors provide more information (operating, reliability, and cost data) to demonstrate the commercial viability of their CCTs.

In addition, although the vendors were invited to attend the participant presentations, only one vendor took advantage of this invitation. Most vendors were available only for a short time after their scheduled presentation. In future seminars, it is recommended that the vendors be available, at the very least, through the end of the day on which they make their presentation. This step would allow the participants more time to assimilate the technology presented and to discuss vendor-specific information on a one-on-one basis.

As for the methods of analyzing the economic competitiveness of CCTs, the spreadsheet tools presented during the seminar were used by most of the participants. However, because of a lack of data from the vendors along with a very busy schedule, there was not sufficient time to work with these tools in detail. The length of this seminar limited the amount of time that could be allocated to technical analysis. The technical analysis is considered to be very useful in this type of seminar because it provides a common ground on which to evaluate a variety of different technologies.

It was clear that all the countries at the seminar have an interest in CCTs. However, countries are at various levels of readiness to incorporate CCTs into their existing systems. For example, those without existing coal resources need to build infrastructure facilities to handle imported coal. Other countries are quite advanced and have initiated a CCT demonstration project.

Many country participants voiced concern about the risks associated with technologies that are not commercially available. Their concern is understandable because they must invest their limited resources cautiously. This risk aversion is especially strong in countries that are short of capacity. To make a large capital investment and not have any return would be a 
reckless decision. In order for countries to obtain the confidence necessary to invest in CCTs, additional assistance from the United States may be needed to help them evaluate and reduce the risks (capital costs, operating characteristics, availability) associated with technologies that are not yet commercially available. This point should be considered when planning subsequent seminars of this kind and/or in follow-up activities to this seminar.

During the verbal evaluation, several participants said they were disappointed because they did not hear anything about the coal research performed at Argonne. In future seminars, a short time should be made available for the host institute to present its relevant activities. Such a presentation would provide the participants the opportunity to meet researchers and discuss topics of interest that might not otherwise be available.

In response to several participants' written comments about the availability of the presented technologies, it would be useful to review the slate of presented CCTs in terms of their availability. CCTs applicable to the countries selected to participate in the seminar could be assessed. From this preliminary assessment, a list of technologies could be compiled that would provide a better match between vendors and participants. Currently available technologies such as slagging combustors and coal-water mixtures were not adequately represented during this seminar. 


\section{FUTURE ACTIVITIES}

The overall success of this seminar suggests that future offerings be considered. In particular, there are at least two different audiences for a seminar of this scope. The first group would be other countries interested in the technologies presented at this seminar, so that this seminar could be readily repeated with different participants. The second audience would be eastern European countries that migh: require a different set of vendors and different site visits.

The seminar should continue to be held in the United States. Although a regional or in-country seminar has some advantages, it would be very difficult to attract vendors to give a 90-minute presentation and pay their own costs. Furthermore, the site visits, which were the most highly rated activity during the seminar, would not be possible at all. The site visits allowed the participants to relate the concepts discussed in the vendor presentations to realworld requirements.

The participants attending this seminar received much new information about CC.Ts. To complete the evaluation, a follow-up questionnaire to examine the need of participants for additional information and appropriate contact people would be beneficial. In addition to participant follow-up, a brief questionnaire to the vendor participants would provide additional insights into the effectiveness of the seminar.

The potential to evaluate the economic and technological aspects of CCTs with existing software tools is very limited. Many countries have expressed interest in enhancements to the Wein Automatic System Planring Package (WASP). WASP is an optimization program that does least-cost expansion analysis for the electric sector. The current version of WASP is available within the Energy and Evaluation Program (ENPEP) for personal computers (PCs). ENPEP contains modules that provide integrated resource planning from demand forecasting to electric system expansion and environmental analysis. WASP and ENPEP/WASP have been distributed to more than 40 countries by the International Atomic Energy Agency. The current version of WASP cannot model staged construction, nor can it consider the addition of steam turbines to existing combustion turbines for more efficient operation. Argonne staff could modify WASP to provide an adequate representation of these new technologies, followed by training for and distribution to representatives of countries interested in CCTs.

The seminar cosponsors are very interested in promoting CCT development in foreign countries. DOE has several outreach programs that assist countries in the transfer of CCT technology. Current activities within the DOE Coal and Technology Export Program include participation in U.S. government interagency coordination and cooperation activities, cooperation with coal and technology industries and trade associations, and international agreements. DOE is also funding prefeasibility studies by U.S. companies on international energy trade and development. Future DOE activities include coal and technology trade missions, a seminar on economics and commercial implementation technologies, and an international coa! and technology symposium and exposition for U.S. technologies and vendors.

In response to the participants' concerns about the limited operational experience with CCTs, DOE has put all participants on the mailing list for the CCT newsletter Clean Coal Today. The newsletter provides information on the status of projects in the CCT demonstration program and information on recently completed reports. Argonne could become involved in tracking the 
CCT program activities and in providing input for the DOE newsletter being sent to the seminar participants.

AID is currently funding five major programs that provide technical and training assistance directly applicable to CCT power development:

- The Energy Technology Innovation Project (ETIP) is a $\$ 20$ million, 11-year project to identify, develop, and realize public-sector energy-capital projects involving production of indigenous resources, CCT power plants, environmental control projects, energy transmission and distribution, solid waste energy recovery, and cogeneration. ETIP undertakes public-sector technical assessments and feasibility studies that address technological, economic, financial, and environmental issues related to projects to improve the effectiveness and efficiency of energy sector management and operations. ETIP emphasizes energy solutions that are more efficient, more cost effective, less capital intensive, and more environmentally benign than conventional technology.

ETIP also addresses the critical problem of financing energy projects by treating financing as an integral part of project development and by designing project-specific financing schemes. ETIP works closely with the U.S. energy industry as well as with major private and multilateral financing institutions.

- The Innovation Energy Projects Prefeasibility Fund provides an effective means for the U.S. energy industry to participate in the formation of major public-sector energy-capital projects in direct competition with subsidized foreign technology suppliers. This fund provides cofunding for a wide spectrum of prefeasibility studies for public-sector energy-capital projects. Also, by enhancing the U.S. energy industry's ability to undertake energy capital projects for developing countries, it provides for significant downstream exports of U.S. equipment and services.

- Private Sector Energy Development is a $\$ 21.8$ million, 6-year project to stimulate and accelerate the development of private energy and power projects in developing countries by encouraging private investment in capital projects, rationalizing tariffs, identifying policy barriers, enhancing understanding of the requirements of power project developers, mitigating risks and expenses, and enhancing understanding of project financing, leasing, and management contracts.

These goals are accomplished through policy reform and institutional development, through private energy and power project development, and through program coordination with other federal agencies and donors as well as with multilateral development banks. Specific activities include:

- Identifying the potential for, and the impediments to, private energy and power development in selected countries. 
- Providing technical support in developing and implementing private energy and power policies and projects.

- Collecting and disseminating information pertaining to private energy and power in developing countries.

- The Private Sector Energy Development Feasibility Study Fund shares with private-sector companies the cost of prefeasibility and feasibility studies and other development activities for private energy and power projects.

- The Energy Training Program (ETP) designs and manages energy-related training activities to meet the specific needs of governmental, parastatal, and private employers in developing nations. Courses range from energy planning and petroleum management to utility engineering and energy efficiency improvement; they typically last from two to seven months. ETP courses emphasize the "hands"on" approach in actual work settings. Participants are encouraged to bring data from their own countries to work on so they can return home with a realistic, workable solution to some aspect of their countries' energy problems.

TDP carries out feasibility studies, consultancies, training programs, and other project planning services that could be requested to assist in a country's evaluation and selection of a U.S. CCT. 
APPENDIX A:

\section{LIST OF PARTICIPANTS}




\section{APPENDIX A:}

\section{LIST OF PARTICIPANTS}

\section{CHILE}

Hans G. Georgi

Phone: 56-2-6323909

Chilgener S.A.

Miraflores 222 -- 7th Floor

Santiago, Chile

Carlos Ribbeck

Phone: 56-2-6332962

Chilgener S.A.

Miraflores 222 -- 7th Floor

Santiago, Chile

Raul I. Sandoval

Chilgener S.A.

Miraflores 222 -- 7th Floor

Santiago, Chile

Phone: 56-2-6323909

\section{COSTA RICA}

Guillermo E. Alvarado

Phone: 20-74-41

Instituto Costarricense de Electricidad

Jefe Direccion Produccion y Transporte de Energie

P.O. Box 10032-1000 San Jose

Costa Rica

Rudolfo Brenes

Phone: 20-78-80

Instituto Costarricense de Electricidad

P.O. Box 10032-1000 San Jose

Costa Rica

Mario Lopez

Phone: $20-70-46$

Instituto Costarricense de Electricidad

20-75-37

Departamento Proyectos de Generacion

PISO 6, Oficinas Centrales

Sabana Norte, San Jose

Costa Rica 
INDIA

Ram K. Iyengar

Ministry of Science and Technology

Council of Scientific and Industrial Research

Rafi Marg

New Delhi, 110 001, India

Narayanswami Ramji

Ministry of Energy

Department of Power

Room 419, 4th Floor

Shram Shakti Shawan

Rafi Marg

New Delhi, 110 001, India

\section{INDONESIA}

Mr. Suhartoyo

PLN State Electricity Corp. of Indonesia

J1. KS Tubun $1 / 2$

Jati Petamburan

Jakarta 11420, Indonesia

\section{Ibrahim Rachmat}

PLN Generating and Transmission

Western Java

J1. KS Tubun No. 8

Jati Petamburan

Jakarta 11420, Indonesia

Luluk Sumiarso

Directorate General of Electric Power and New Energy

Department of Mines and Energy

Jln. H.R. Rasuna Said Kav. X-2/07-08

Jakarta, Indonesia
Phone: 384-159

Phone: 3710389
Phone: 62-21-5492770

5492771

Phone: 62-21-548522

Phone: 62-21-516066

\section{MEXICO}

Juan J. Ramirez Solis

Phone: 553-91-19

Director de Investigacion

$553-37-98$

Direccion General de Investigacion y Desarrollo

Francisco Marquex 160, 3 PISO

Col. Condesa

Mexico, DFCP. 06140 


\section{PHILIPPINES}

Teddy P. Casacop

Office of Energy Affairs

Conventional Resources Division

Merritt Road, Port Bonifacio

Makati, Metro Manila

Philippines

Bienvenido A. Babilonia

National Power Corporation

Thermal Power loc. 322

Engineering Department

Diliman, Quezon City

Philippines
Phone: 632-857487

Phone: 921-35-41
TAIWAN, ROC

Iruang Wu

Energy Commission

Ministry of Economic Affairs

13th $\mathrm{Fl} / \mathrm{No} .2$

Flj-Hsing North Road

Taipei, 100, Taiwan, ROC

Hong-Neng Wu

Taiwan Power Company

22F, 242 Roosevelt Road

Taipei, 100, Taiwan, ROC

Yuung-Yuarn Lin

aka Martin Y.Y. Lin

Taiwan Power Company

Fuel Department

9F, 242 Roosevelt Road

Section 3

Taipei, 100, Taiwan, ROC

Wuu-Huang Lin

Taiwan Power Company

Environmental Protection Department

21F, 242 Roosevelt Road

Section 3

Taipei, 100, Taiwan, ROC
Phone: 886-2-772-1370

Phone: 886-2-397-6733

Phone: 886-2-397-6733

Phone: 886-2-397-7207 
Dennis Huachung Tsui

Phone: 886-35-966100

Researcher

Fuel Application Section

Energy and Resource Laboratory

Building 64

195 Chung Hsing Road, Section 4

Chutung Hsinchu, Taiwan 31015, ROC 
APPENDIX B:

LIST OF ATTENDEES 
APPENDIX B:

LIST OF ATTENDEES

VENDOR LIST

Bill Campbell

W.W. Kellogg Company

601 Jefferson Avenue

Houstor, Texas 77210-4557

Paul Gatzemeier

Western Energy Company

P.O. Box 7137

Billings, Montana 59103

Elias Gedeon

Foster Wheeler Energy Corporation

Perryville Corporate Park

Clinton, New Jersey 08809-4000

M. Rao Gogineni

ABB Combustion Engineering Systems

1000 Prospect Hill Road

Windsor, Connecticut 06095-0500

\section{Anthony V. Harrington}

Foster Wheeler Energy Corporation Dept. 166

Perryville Corporate Park

Clinton, New Jersey 08809-4000

Clark Harrison

$\mathrm{CQ}$, Inc.

One Quality Center

Homer City, Pennsylvania 15748-0280

John Hollback

American Electric Power Service Corporation

1 Riverside Plaza

Columbus, Ohio 43215

Todd Johnson

Babcock \& Wilcox/Contract Research Division 1562 Beeson Street

Alliance, Ohio 44601-2196
Phone: (713) 753-2184

Fax: (713) 753-5353

Phone: (406) 252-2277

Fax: (406) $252-2090$

Phone: (908) 730-4000

Fax: $\quad$ (908) 730-4360

Phone: (203) 285-2502

Fax: (203) 285-3861

Phone: (908) 730-5452

Fax: (908) 730-4559

Phone: (412) 479-6016

Fax: (412) 479-4181

Phone: (614) 223-1749

Fax: (614) 223-3204

Phone: (216) 829-7355

Fax: (216) 829-7801 
J. G. Patel

Tampella Power Corporation

2300 Windy Ridge Parkway Suite 1125

Marietta, Georgia 30067

Mark Roll

Destec Energy, Inc.

2500 City West Boulevard Suite 1700

Houston, Texas 77042

Edward S. Sadlon

ABB Combustion Engineering Systems

1000 Prospect Hill Road

Windsor, Connecticut 06095-0500

Frank Schora

MC Power

8040 S. Madison Street

Burr Ridge, Illinois 60521-5808

Skip Vroom

ABB Combustion Engineering Systems 1000 Prospect Hill Road

Windsor, Connecticut 06095-0500

Douglas A. Wert

AHLSTROM Development Corporation

8925 Rehco Road

San Diego, California 92121

Walter Wolowodiuk

Foster Wheeler Energy Corporation

12 Peach Tree Hill Road

Livingston, New Jersey 07039
Phone: (404) 984-8871

Fax: (404) 956-9284

Phone: (713) 974-8308

Fax: (713) $974-8358$

Phone: (203) 285-3958

Fax: (203) 285-5301

Phone: (708) 986-8047

Fax: (708) 986-8086

Phone: (203) 285-9085

Fax: (203) 285-9084

Phone: (619) 458-3071

Fax: (619) 457-0855

Phone: (201) 535-2323

Fax: (201) 535-2242

ARGONNE STAFF

Bill Buehring

Argonne National Laboratory

9700 S. Cass Avenue

Argonne, Illinois 60439-4832

Jerry Gillette

Argonne National Laboratory

9700 S. Cass Avenue

Argonne, Illinois 60439-4832
Phone: (708) 252-3785

Fax: (708) 252-6073

Phone: (708) 252-7475

Fax: (708) 252-6073 
Karen Guziel

Argonne National Laboratory

9700 S. Cass Avenue

Argonne, Illinois 60439-4832

Aine O'Carroll

Argonne National Laboratory

9700 S. Cass Avenue

Argonne, Illinois 60439-4832

Carol Partilla

Argonne National Laboratory

9700 S. Cass Avenue

Argonne, Illinois 60439-4832

Les Poch

Argonne National Laboratory

9700 S. Cass Avenue

Argonne, Iliinois 60439-4832
Phone: (708) 252-3273

Fax: (708) 252-4548

Phone: (708) 252-7786

Fax: (708) 252-5327

Phone: (708) 252-3386

Phone: (708) 252-8129

Fax: (708) 252-6073

\section{OTHER SEMINAR ATTENDEES}

Suman Babbar

World Bank

Room No. D-3045

1818 H Street

Washington, D.C. 20433

Rita Bajura

Morgantown Energy Technology Center

P.O. Box 880

Morgantown, West Virginia 26505

John J. Beardsworth, Jr.

Hunton \& Williams

Riverfront Plaza, East

Richmond, Virginia 23219

Larry Carpenter

Morgantown Energy Technology Center

P.O. Box 880

Morgantown, West Virginia 26505

Peter Cover

U.S. Department of Energy

1000 Independence Ave. SW (FE-4)

Washington, D.C. 20585
Phone: (202) 458-0147

Fax: (202) 477-1822

Phone: (304) 291-4190

Fax: (304) 291-4469

Phone: (804) 788-8637

Fax: (804) 788-8218

Phone: (304) 291-4161

Fax: (304) 291-4469

Phone: (202) 586-7297

Fax: (202) 586-1188 
Don Dowling

Cogentrix, Inc.

9405 Arrowpoint Boulevard

Charlotte, North Carolina 28273-8110

Casters (Cass) Foster

U.S. Department of Energy

1000 Independence Ave. SW

Washington, D.C. 20585

John Hammond

PSED

1611 N. Kent Street Suite 200

Arlington, Virginia 22209

David J. Jhirad

U.S. Agency for International Development

Office of Energy

Sat/Ey 508, SA-18

Washington, D.C. 20523

Michael L. Jones

Energy and Environmental Research Center

P.O. Box 8213 University Station

Grand Forks, North Dakota 58201

Frederick V. Karlson

Bechtel

1601 N. Kent Street Suite 914

Arlington, Virginia 22209

C. Lowell Miller

U.S. Department of Energy

1000 Independence Ave. SW

Washington, D.C. 20585

Steve Oldoerp

U.S. Department of Energy

1000 Independence Ave. SW

Washington, D.C. 20585

Dianne Rudo

Institute of International Education

1400 K Street NW

Washington, D.C. 20008

Alberto Sabadell

U.S. Agency for International Development

Washington, D.C. 20523-1810
Phone: (704) 525-3800

Fax: (704) 529-5313

Phone: (202) 586-5000

Fax: (202) 233-2303

Phone: (703) 524-4400

Fax: (703) 524-3164

Phone: (703) 875-4047

Fax: (703) 875-4053

Phone: (701) 777-5152

Fax: (701) 777-5181

Phone: (703) 528-4488

Fax: (703) 528-2280

Phone: (202) 586-7150

Fax: (202) 586-7316

Phone: (202) 586-7164

Fax: (202) 586-5049

Phone: (202) 682-6560

Fax: (202) 682-6576

Phone: (703) 875-4056

Fax: (703) 875-4394 
Dan Stein

U.S. Trade and Development Program

Washington, D.C. 20523

Jim Sullivan

U.S. Agency for International Development

Washington, D.C. 20523-1810

Denise Swink

U.S. Department of Erergy

1000 Independence Ave. SW (FE-4)

Washington, D.C. 20585
Phone: (703) 875-4357

Fax: (703) 875-4009

Phone: (703) 875-4203

Fax: (703) 875-4394

Phone: (202) 586-9680

Fax: (202) 586-1188 
APPENDIX C:

SEMINAR SCHEDULE 
APPENDIX C:

SEMINAR SCHEDULE

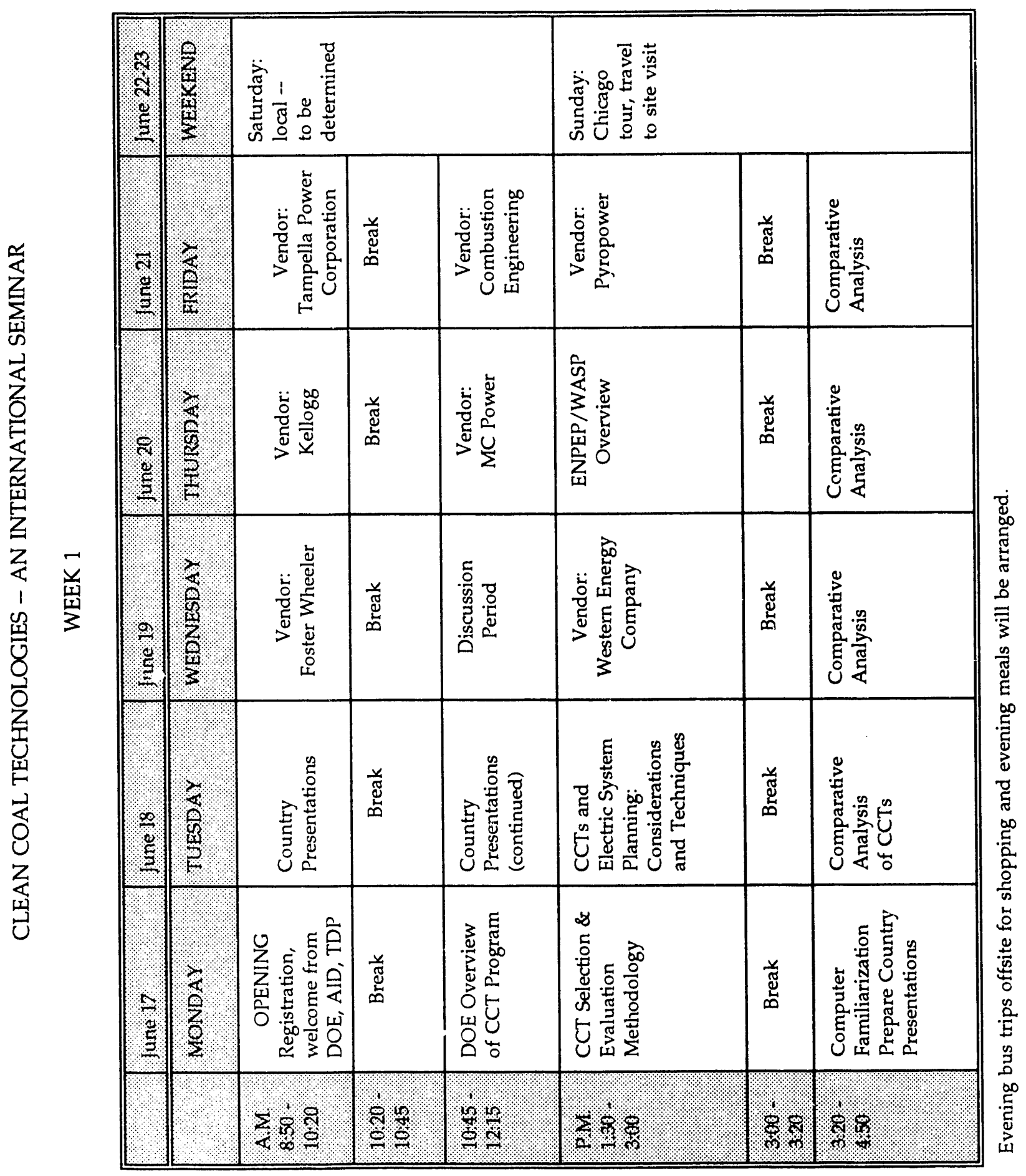




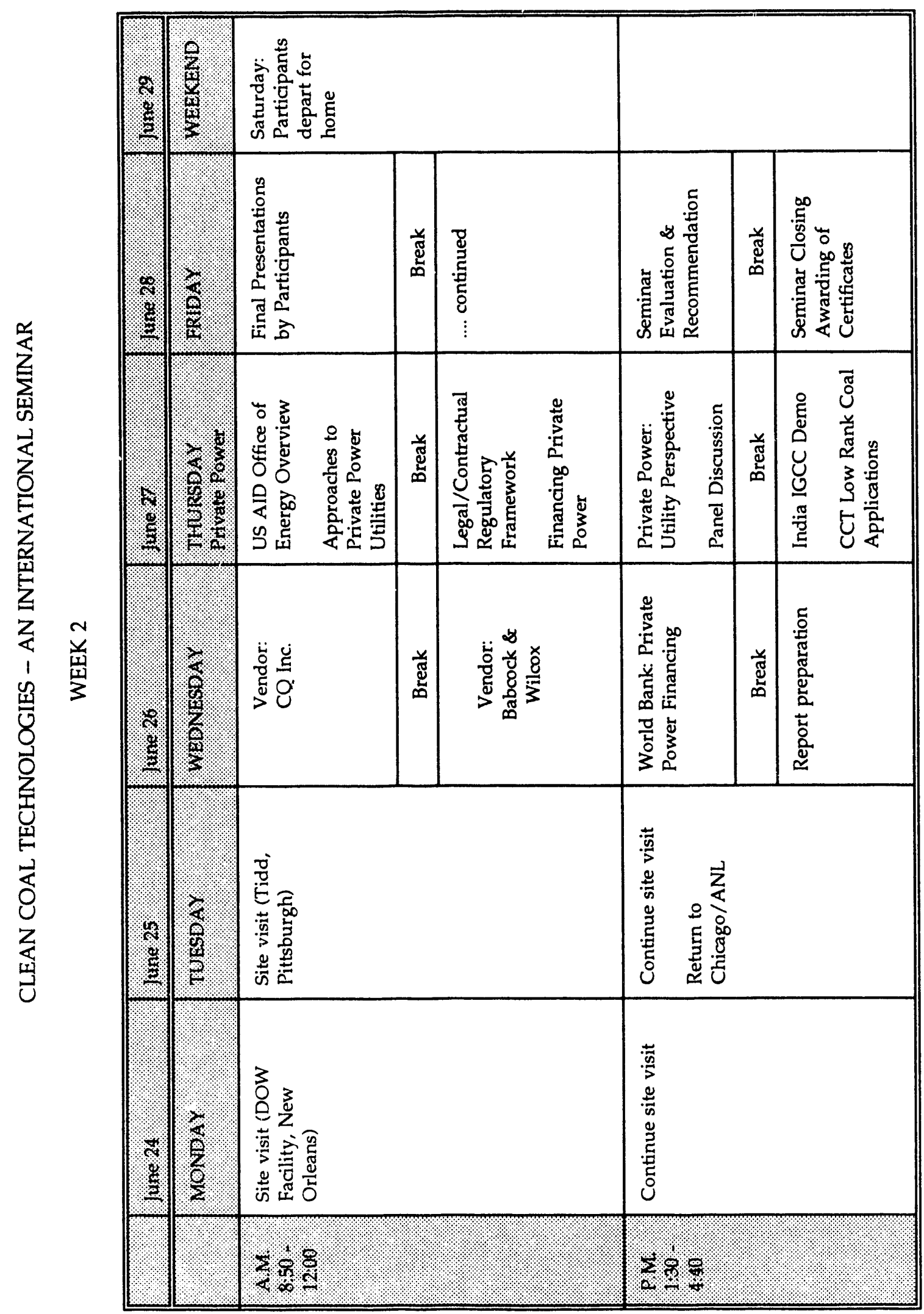

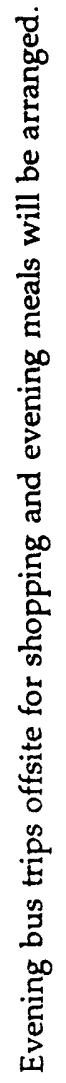


APPENDIX D:

QUANTITATIVE EVALUATION RESULTS 


\section{APPENDIX D:}

\section{QUANTITATIVE EVALUATION RESULTS}

\section{CCT SEMINAR EVALUATION SCORES}

Presentation/Activity

Average

Overview of U.S. National Energy Strategy and International Market

Opportunities for U.S. Clean Coal Technologies

Score*

Office of Energy, U.S. Agency for International Development, Clean Coal Technology Demonstration Program

CCT-IV Proposal Selection and Evaluation

Country Presentations

Clean Coal Technologies and Electric System Planning: Considerations and Techniques

Comparative Analysis of CCTs -- Screening Curve

Foster Wheler Presentation

MC Power Presentations

MC Power Site Visit

Kellogg Presentation

Western Energy Co. Presentation

ENPEP/WASP Overview

$\begin{array}{ll}\text { Tampella Power Corp. Presentation } & 1.78\end{array}$

ABB Combustion Engineering Presentation $\quad 1.58$

$\begin{array}{ll}\text { Pyropower Presentation } & 1.63\end{array}$

$\begin{array}{lr}\text { Comparative Analysis } & 1.78\end{array}$

Destec Presentation $\quad 1.32$

$\begin{array}{ll}\text { Destec Site Visit } & 1.26\end{array}$

Tidd Plant Presentation $\quad 1.32$

Tidd Plant Site Visit $\quad 1.11$

$\begin{array}{ll}\mathrm{CQ} \text { Inc. Presentation } & 1.58\end{array}$

The World Bank: Private Power Financing $\quad 2.42$

Babcock \& Wilcox Presentation $\quad 1.63$

U.S. AID Office of Energy Overview $\quad 2.16$

Overview of Private Power in Developing Countries $\quad 2.37$

Legal and Contractual Requirements for Private Power Projects $\quad 2.47$

$\begin{array}{ll}\text { Financing Private Power } & 2.53\end{array}$

*The average score was determined by individual ratings for each of the presentations. Each participant was asked to rate each presentation on a scale from 1 to 4 where:

$$
\begin{aligned}
& 1=\text { very valuable, } \\
& 2=\text { valuable, } \\
& 3=\text { somewhat valuable, and } \\
& 4=\text { not valuable. }
\end{aligned}
$$

This rating structure implies that the lower the average rating the more valuable the presentation was considered to be. 


\section{CCT SEMINAR EVALUATION SCORES (CONT'D)}

Presentation/Activity

Average

Private Power Financing -- The Utility Perspective $\underline{\text { Score* }}$

IGCC Demonstration Project in India

Clean Coal Technologies: Low Rank Coal Perspective

1.74

USAID Panel Discussion

1.37

1.95

*The average score was determined by individual ratings for each of the presentations. Each participant was asked to rate each presentation on a scale from 1 to 4 where:

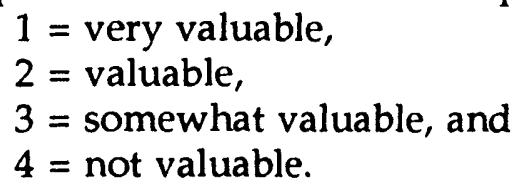

This rating structure implies that the lower the average rating the more valuable the presentation was considered to be. 


\section{CCT SEMINAR EVALUATION STATISTICS}

$\begin{array}{cccc}\text { Just Right } & & \text { Too Short } & \text { Too Long } \\ 14 & 5 & \\ 10 & 3 & 6 \\ 5 & 13 & 1 \\ 8 & 2 & 8 \\ 17 & 1 & 1 \\ 8 & 11 & 0\end{array}$

Overall Seminar Length

Vendor Presentations

Site Visits

Financial Presentations

Country Presentations

Technical Presentations
Spreadsheet

CCT Evaluation

Screening Curve
Used

10

15
Didn't Use

7

4 

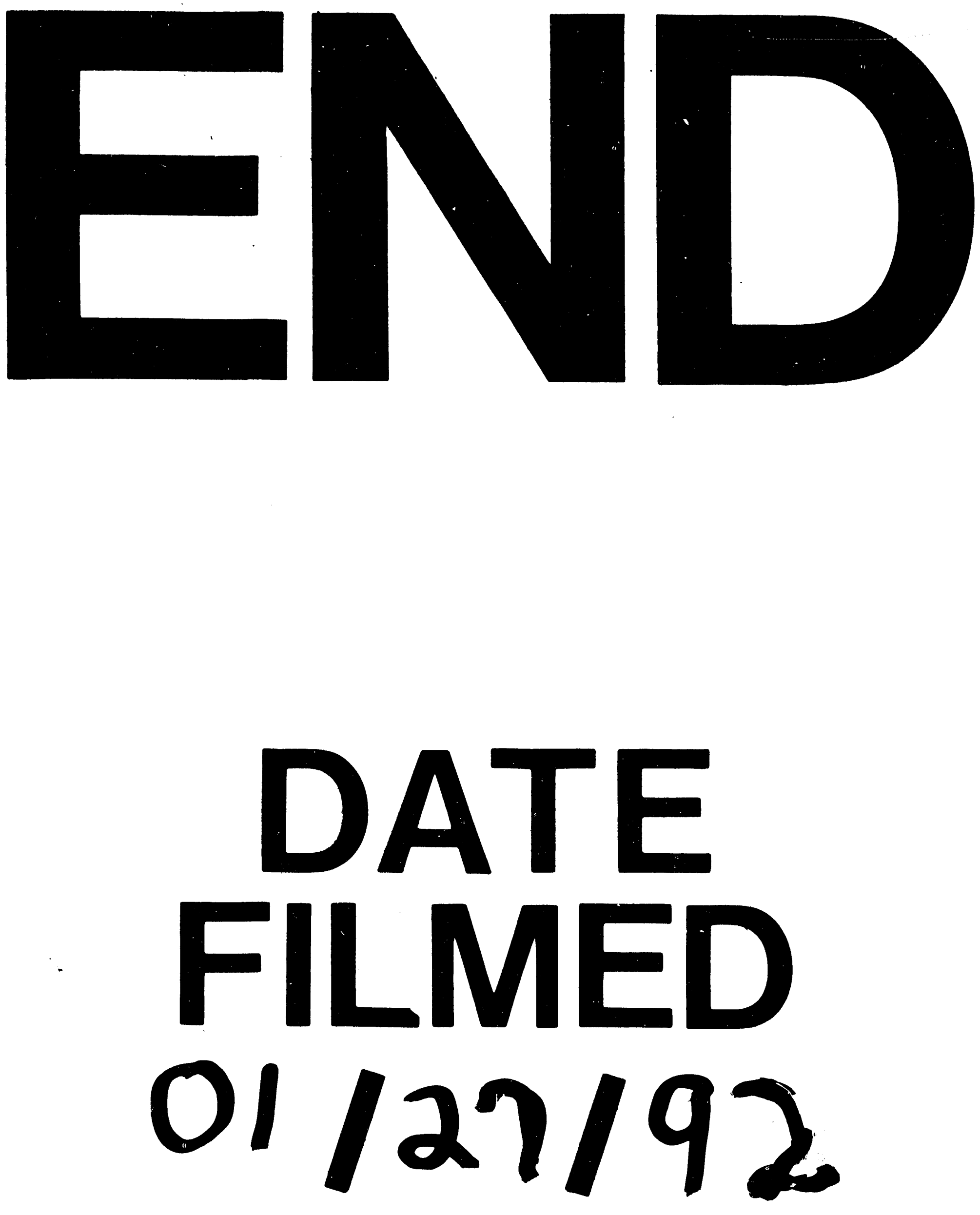

$-1$ 